The Historical Journal, 64, 5 (2021), pp. 1230-1256 (C) The Author(s), 2021 . Published by Cambridge University Press. This is an Open Access article, distributed under the terms of the Creative Commons Attribution-NonCommercial-ShareAlike licence (http://creativecommons. org/licenses/by-nc-sa/4.o), which permits non-commercial re-use, distribution, and reproduction in any medium, provided the same Creative Commons licence is used to distributed the re-used or adapted article and the original article is properly cited. The written permission of Cambridge University Press must be obtained prior to any commercial use.

doi:10.1017/SoO18246X21000029

\title{
RURAL WORKERS AND THE ROLE OF THE RURAL IN EIGHTEENTH-CENTURY ENGLISH FOOD RIOTING
}

\author{
CARL J. GRIFFIN \\ University of Sussex
}

\begin{abstract}
A B S T R A C T. No form of English popular protest has been subject to such close scholarly analysis as the eighteenth-century food riot, a response not just to the understanding that food riots comprised two out of every three crowd actions but also to the influence of E. P. Thompson's seminal paper 'The moral economy of the English crowd'. If the food riot is now understood as an event of considerable complexity, one assertion remains unchallenged: that riots remained a tradition of the towns, with agrarian society all but unaffected by food rioting. This article offers a new interpretation in which the rural is not just the backdrop to food protests but instead a locus and focus of collective actions over the marketing of provisions, with agricultural workers taking centre stage. It is shown that agricultural workers often took the lead in market town riots as well as well as in instigating riots in the countryside. Further, such episodes of collective protest were neither rare nor unusual but instead formed an integral part of the food rioting repertoire. It is also shown that rural industrial workers-notoriously active in market town riots-were often joined or even led by agricultural workers in their protests.
\end{abstract}

The eighteenth century was the age of the riot. Whilst any number of contentious subjects provoked riots - from elections to enclosure, and workhouses to wages - it was the 'food riot' that was the archetypal form, accounting for two out of three 'disturbances'. ${ }^{1}$ Waves of regional rioting in 1709-10 and $1727-$ 9 were followed by national waves in $1740,175^{6-7}, 1766-7,1772-3,1783-4$,

University of Sussex, Falmer, Sussex, BNI 9SJ carl.griffin@sussex.ac.uk

${ }^{1}$ Adrian Randall, Riotous assemblies: popular protest in Hanoverian England (Oxford, 2006), pp. 1-2; John Archer, Social unrest and popular protest in England, I780-I84O (Cambridge, 2000), p. 28. 
and $1795^{-6}, 1800-1$ representing the last genuinely national 'wave' of extensive food rioting. If food rioting was neither universal nor ubiquitous, it was certainly far more present in the public consciousness than any other form of disturbance. $^{2}$ The importance of food rioting as both a protest practice and as a vehicle for the collective voice of the English subaltern is reflected in its relative dominance of what has become known as the field of protest history. If the historiography of food rioting goes back to at least the publication of John and Barbara Hammond's The village labourer in 1911-the study that famously labelled the protests of the 1795 subsistence crisis as 'the revolt of the housewives' - it was arguably not until E. P. Thompson's 1971 study 'The moral economy of the English crowd in the eighteenth century' that the food riot assumed its current criticality. ${ }^{3}$ As John Archer put it, food riots have been 'subject to greater and closer analysis than any other form of popular protest and, as a result, the seemingly straightforward food riot has become an event of enormous complexity and variety'. ${ }^{4}$ Some twenty years after Archer's study, notwithstanding the broadening of the field in the recent renaissance of protest studies in what Katrina Navickas has labelled the 'new protest history', 5 the point still holds: the food riot continues to dominate our studies and understandings of popular protest in eighteenth-century England.

Herein an apparent paradox. Eighteenth-century England was a country that was economically and geographically dominated, culturally defined, and politically governed by the agrarian interest. The largest and dominant occupational group were those who worked in agriculture, the wage labourers who toiled in the fields, farmyards, and gardens for their employer. Yet, the food riot-in which the produce of the countryside was the silent protagonist-was, as received understanding has it, an urban phenomenon. Or as John Bohstedt asserted, 'riot remained a tradition of the towns'; '[a]grarian society was nearly untouched by riot' ${ }^{6}$ While we now understand that a muscular culture of protest was alive and well in agrarian communities in eighteenth-century

2 Andrew Charlesworth, ed., An atlas of rural protest in Britain, 1548-19oo (London, 1983), pp. $83-111$.

3 John Hammond and Barbara Hammond, The village labourer, I760-I 832: a study in the government of England before the Reform Bill (London, 1911), pp. 120-2; E. P. Thompson, 'The moral economy of the English crowd in the eighteenth century', Past E Present, 50 (1971), pp. 76136. R. B. Rose's 1961 paper 'Eighteenth-century price riots and public policy in England' was also an important pre-Thompsonian landmark: R. B. Rose, 'Eighteenth-century price riots and public policy in England', International Review of Social History, 6 (1961), pp. $277-92$.

4 Archer, Social unrest, 28.

5 Katrina Navickas, 'What happened to class? New histories of labour and collective action in Britain', Social History, 36 (2012), pp. 192-204. For an excellent survey of this reawakening, see Hannah Awcock, 'New protest history: exploring the historical geographies and geographical histories of resistance through gender, practice, and materiality', Geography Compass, 14 (2020), e12491.

6 John Bohstedt, Riots and community politics in England and Wales, I790-I 8 Io (Cambridge, MA, 1983), pp. 166, 169, 270. 
England, 7 the interpretation of food riots still places them all but exclusively in the urban and industrial spheres. Further, as Thompson put it, in comparing food rioting in England with ancien régime France, 'farm labourers' were notable for their 'relative inactivity'. If agricultural workers were to be found food rioting it was because 'some other group (like colliers) formed the original nucleus, or where some activity [such as in gangs of "bankers", those engaged in creating embankments and cleaning out drainage channels] brought them together in sufficient numbers'. ${ }^{8}$ Occasionally, urban residents might 'scour' the countryside to find withheld grain and compel farmers to bring such supplies to market at agreed prices, but it was urban markets that provided both the psychic and physical focus of food rioting.9 Of course, Thompson and those that have followed in his footsteps were alert to the fact that groups such as colliers and clothworkers were invariably resident in the countryside and took an often leading role in many marketplace food riots. Yet whilst Thompson acknowledged that such workers were 'never far from the sight of corn', the connection to the agrarian world and to agricultural workers is not made. Or, as Andrew Charlesworth and Adrian Randall have it, the protests of such workers 'formed part of a wider rebellious plebeian culture which, though nurtured in a superficially rural environment, was based on smallscale capitalist production, upon the independent quasi-artisan relations of the small workshop and cottage'. ${ }^{10}$

This article offers a new interpretation in which the rural is not just the backdrop to food protests - as little more than the space of production - but instead a locus and focus of collective actions over the marketing of provisions, with agricultural workers taking centre stage. This is not to deny the central importance of the towns, and in particular urban markets, as the dominant foci of protest. Indeed, as it will be shown, agricultural workers often took the lead in market town riots as well as in riots in the countryside. The distinction that, to quote Charlesworth and Randall again, 'industrial workers lived at the sharp end of an ever-evolving capitalist market economy and experienced exploitation not only in the market place but, more crucially, at work' and agricultural workers did not is overplayed. ${ }^{11}$ Rather, the point is to show that focusing only upon the actions of urban and industrial workers acts to distort seriously our understandings and renders food riots too spatially and sociologically simplistic.

What follows draws upon a diverse range of archives, primarily drawn from the southern and western counties and the North Riding of Yorkshire,

7 For surveys, see Charlesworth, ed., Atlas of rural protest; Carl Griffin, Protest, politics and work in rural England, I $700-1850$ (Basingstoke, 2014).

8 Thompson, 'Moral economy', p. 119.

9 Ibid., pp. 79, 111.

${ }^{10}$ Ibid., p. 99; Andrew Charlesworth and Adrian Randall, 'Morals, markets and the English crowd in 1766', Past EF Present, 114 (1987), pp. 200-13, at p. 206.

11 Ibid., p. 206. 
principally provincial press reports, Home Office and War Office correspondence, and judicial records. The analysis does not follow a bounded chronology, rather the rest of the article - after first considering the ways in which existing work has written (or rather written out) the rural in food rioting - is structured around three themes before concluding. First, an analysis of rural food riots in which agricultural labourers took a leading role. Second, an examination of agricultural labourers and other rural non-industrial workers' involvement in market town riots. Third, an exploration of how many rural workers led a hybrid geographical and occupational existence and as such that many riotous assemblies were heterogeneous in their composition.

Given the famed complexity of food rioting, lucidly rendered by Thompson in his now fifty-year-old paper, there is a remarkable degree of unanimity as to whom food rioters were and where they were from. In the words of John Stevenson, food riots were not the work of the crowd 'in the sense of a representative section of the common people' but rather were 'the protests of a minority section of the population - the urban dweller'. If Stevenson also allowed for the fact that some riots did occur in villages, and indeed that some towns supposedly never witnessed 'disturbances', whatever the location it was still invariably the industrial and urban workers that were the protagonists. ${ }^{12}$ Such is the consensus. For Thompson, '[ $\mathrm{t}]$ he occupational make-up of the crowd provides few surprises'. If the key protagonists were sometimes, in the words of a south-western observer quoted by Thompson, 'the inferior Tradesmen, Woolcombers, \& Dissenters, who keep aloof but by their language \& immediate influence govern the lower classes', the composition of the crowd was 'fairly representative of the occupations of the "lower Orders" in the rioting areas'. Thus, in towns we see a broad cross-section of (depending precisely on the location) trades, industrial workers, artisans, and labourers, while, as noted above, in the villages tradesmen, artisans, clothworkers, and miners took the lead. ${ }^{13}$

A useful refinement of this model was proposed by Bohstedt, initially in his 1983 book Riots and community politics and further extrapolated in several subsequent studies. Riots, ostensibly a comparison of the differing food rioting practices in Devon and Manchester, posited that outside of London there were three community types that rioted: industrial towns, small market towns, and villages with a strong industrial or mining base. A later revision saw the number of categories expanded to five: London; large and rapidly growing industrial 'boom towns'; stable, medium-sized towns; rural industrial villages; and small

${ }^{12}$ John Stevenson, 'The "moral economy" of the English crowd: myth and reality', in Anthony Fletcher and John Stevenson, eds., Order and disorder in early modern England (Cambridge, 1985), p. $23^{6 .}$

13 Thompson, 'Moral economy', pp. $118-19$. 
agrarian villages (with a maximum population size of 3 ,ooo) ${ }^{14}$ In his sample of 617 eighteenth-century riots - note, this included all forms of crowd action involving at least $5^{\circ}$ people-only 7 per cent were located in settlements with a population lower than 1,5 oO, his qualification for being rural. ${ }^{15}$ 'Country people' did not need to riot anyhow being 'shielded from market fluctuations by receiving parish relief' and being able to access grain directly from farmers often at below-market-rates - or through pilfering. The labourer was locked into a 'stifling dependence'; the 'revenges of village paternalism'. ${ }^{16}$ Their subsistence needs met, agricultural workers had no need to go to urban marketsthe locus of food rioting-and even if they did wish to engage in riot they were unable to challenge their employers for fear of losing their work and their poor relief. On the rare occasion then that rural workers did openly resist, not understanding the rituals of the urban moral economy their protests were 'undisciplined'. The one exception to this 'rule' was Norfolk where 'farm workers were already involved in an agricultural system more orientated toward capitalist practices than most of rural England' and had less to lose by collective action. ${ }^{17}$ In his most recent study, Bohstedt's argument remains essentially unaltered: all agricultural labourers were pauperized and in this state of 'dependency', 'reinforced by the heavy stability of rural poverty', the 'rural poor' dare not engage in 'the politics of provisions' and hence 'were almost never identified among food rioters'. ${ }^{18}$

If Bohstedt's is the most detailed exposition, other studies - however critical of his model of typology of riotous communities ${ }^{19}$ - have broadly concurred with his assessment as to the urban-industrial/agrarian geography of English food rioting. To Charlesworth and Randall, riots in agrarian communities were 'extremely rare' because 'farmers ensured that their labourers and farm servants obtained food, either by selling at reasonable prices or by looking the other way when pilfering occurred'. Agricultural labourers' 'dependent situation' on farmers and dealers, 'to them men of real power and influence', meant they 'stood a much higher chance of being recognized than the weavers, miners and nailers who came as strangers to set the price'. ${ }^{20}$ Rather, the major centres of food rioting were communities of industrial workers because:

${ }^{14}$ Bohstedt, Riots and community politics, p. 168; idem, 'Gender, household and community politics: women in English riots, 1790-1810’, Past Eं Present, 120 (1988), pp. 88-1 22, at p. 106.

${ }^{15}$ Ibid., pp. 106 n. 58, 166. For a further analysis of this point, see Andrew Charlesworth, 'From the moral economy of Devon to the political economy of Manchester, 1790-1812', Social History, 18 (1993), pp. 205-17.

16 Bohstedt, Riots and community politics, p. 170; Thompson, 'Moral economy', p. 119.

17 Bohstedt, Riots and community politics, pp. 45, 168-9, 171-2.

18 John Bohstedt, The politics of provisions: food riots, moral economy, and market transition in England, c. $155^{\circ}-185^{\circ}$ (Farnham, 2010), p. 43 .

19 For a thorough critique, see Charlesworth, 'From the moral economy of Devon', passim.

${ }^{20}$ Charlesworth and Randall, 'Morals, markets and the English crowd', p. 202. 
$[\mathrm{O}]$ nly these communities possessed the capacity to generate such resistance and the social cohesion to be successful. These were the unmanageable manufacturing districts, where there were large concentrations of independent and self-assertive workers, where there was a multiplicity of employers or where there was little direct economic control, where the squire and parson had but little sway and habits of deference could not easily be imbued. ${ }^{21}$

The difference, then, was that the small-scale capitalist mode of production of the small workshop and cottage meant that 'industrial workers lived at the sharp end of an ever-evolving capitalist market economy and experienced exploitation not only in the market-place but, more crucially, at work'. ${ }^{22}$ If historians of the food riot allow for the fact that-after Thompson-many industrial workers lived amidst the cornfields, the idea that theirs was a superficially rural existence prevails. But whilst their modes of production were fundamentally different from the field workers, they still lived in and collectively comprised the same communities as agricultural labouring families, being neighbours, family, and friends. We know too that when times were hard clothworkers were forced to find other employment - which invariably meant in agriculture - or to seek the same poor relief as their supposedly dependent labouring cousins, whilst industrial workers would often down their usual tools during the harvest and pick up the sickle or scythe instead. For instance, during the deficient harvest of 1819 , the usual influx of West Yorkshire mill workers into the cornfields of the East and North Ridings failed to materialize, the lack of opportunities despite the 'extraordinary want of labour in the manufacturing districts' curtailing the customary migration. ${ }^{23}$ As Navickas has shown, contra Bohstedt's model, many residents of rapidly industrializing northern towns kept one foot in the country, maintaining close connections to rural cousins and often moving between town and 'semi-rural' neighbourhoods for work and leisure. The division between the industrial and agrarian is overplayed. ${ }^{24}$

In the same way that the industrial and agrarian worlds were not kept hermetically apart, so the rural and urban were not separate spheres. Even agrarian communities in the cornlands outwith the cloth districts were composed of a diverse occupational mix of labourers, artisans, and journeymen, their villages and hamlets linked to surrounding towns and cities through complex webs of kin, capital, and commodity chains. In contrast to Bohstedt's claim, many

21 Ibid., p. 205 .

22 Ibid., p. 206.

23 M. Chase, I 820: disorder and stability in the United Kingdom (Manchester, 2013), p. 12. Dale Williams makes the important point that the local poor law could easily be overwhelmed by the large numbers of clothworkers seeking relief when trade turned sharply down, 'effective aid [being] beyond the power of local resources': Dale Williams, 'Morals, markets and the English crowd in 1766', Past E Present, 104 (1984), p. 62.

${ }^{24}$ Charlesworth, 'From the moral economy of Devon', passim; Katrina Navickas, Loyalism and radicalism in Lancashire, $I_{79}{ }_{-1}{ }_{1}{ }_{15}$ (Oxford, 2009), pp. 169-71. 
agricultural labourers had good reason to attend markets in nearby small towns: in a professional capacity as carters, wagoners, and stock-men and -women bringing their masters' goods to market; in their own capacity as petty producers selling their wares; as consumers purchasing food from the shops, stalls, and shambles; and even occasionally when time permitted for reasons of conviviality, meeting friends and family in taverns and taprooms. As Walter Rose put it in Good neighbours:

Going to the market always brought with it a spirit of hilarity, as well it might, for a good deal of drudgery belonged to village life...The market town welcomed them all with outspread arms... motley crowd jostled; squires and farmers of almost equal status strode amongst yokels who had driven in cattle and sheep and pigs from the farms and were waiting to know what they have to drive back. ${ }^{25}$

We do well to remember too that, as June Sheppherd has shown, large numbers of agricultural labourers were to be found living in towns and their rapidly developing suburbs, walking to work in nearby farms every day. As late as 1861, major urban centres such as Bedford, Colchester, Dorchester, and Maidstone had over 8 per cent of their populations primarily engaged in agricultural labour, this not including general labourers and operatives who also occasionally turned to field-work. The depth of connection has been understated. ${ }^{26}$

Not only were some urban spaces familiar to many agricultural workers but also their very need to engage with markets - in addition to rural shops and higglers - speaks to a profound enmeshment with commercial marketing. Indeed, labourers were no more shielded from the force of the market than industrial workers. After all, both were laid off when work was scarce, both were paid wages largely determined by local labour markets. And both were at the mercy of the same poor law system - or charity. Further, explicit evidence for farmers beneficently supplying their workers with corn at below market rates is scanty. The truck system had a precarious existence during the eighteenth century, several statutes expressly forbidding the practice, and it was not until the inflationary pressures of the early 1790 and then the subsistence crisis of $1794^{-6}$ that its growth was speeded, especially so in East Anglia and parts of the West Country and Midlands. But it was neither popular amongst workers-who were obliged to take what might be low-quality food at inflated prices - nor confined to those engaged in agriculture, industrial employers also adopting such schemes during the crisis. Besides, by the 1790 , most labouring families

25 Walter Rose, Good neighbours: some recollections of an English village and its people (Cambridge, 1949), pp. 82-3.

${ }^{26}$ June Sheppard, 'Agricultural workers in mid nineteenth-century Brighton', Agricultural History Review, 54 (2006), pp. 93-104, data taken from appendix 1. On such interconnections, see Griffin, Protest, politics, and work, pp. ${ }^{-1} 5^{-16}$; Carl Griffin, 'The culture of combination: solidarities and collective action before Tolpuddle', Historical Journal, $5^{8}(2015)$, pp. 443-8o; E. P. Thompson, Customs in common: studies in traditional popular culture (London, 1992), p. 318. 
were not baking their own bread anyhow, in part due to the cost of fuel. In sum, as Wells notes, 'the dependency of rural workers on the market and their exposure to price movements, was not in aggregate radically altered either by the development of truck systems by farmers in some regions, or the marked increase in poor-relief payment throughout the countryside'.${ }^{27}$

Many, if not all, agricultural workers therefore had the means and the motivation to riot. Of course, the larger a community, the freer the population was from forms of social control and surveillance; the higher proportion of individuals absolutely at the mercy of wage labour and piece working, the more likely it was to riot - and the more likely it was to sustain a culture of collective opposition. And, to quote Charlesworth, we know that this culture 'grew stronger and was enriched as a cumulative collective memory of previous struggles' ${ }^{28}$

What then do we know of rural food rioting? Beyond the universal acceptance that many workers who lived in the countryside were key protagonists in the eighteenth-century food riot-the colliers and clothworkers being the most notable example - and beyond Bohstedt's identification of Norfolk as having a distinctive, advanced capitalist agricultural system which removed labourers from modes of control present elsewhere, very little. ${ }^{29}$ Charlesworth and Randall, as detailed above, related that food riots in 'purely agrarian communities...were extremely rare', although in a later study they did allow for the idea that just as there was an industrial moral economy so too was there an agrarian moral economy in which the old reciprocities of the paternalist/moral economy matrix continued to inform values in the countryside well into the nineteenth century'.30 Randall in Riotous assemblies went a little further. 'Country people', he writes, 'were frequently to be found at the margins and even leading smaller local events', but the three examples he details of 'riots' led by 'country people' were all small-scale and involved attempts to prevent the export of wheat or flour from their community. $3^{1}$

Arguably, it is Wells who has come closest to not just allowing for the fact that food riots were not exclusively a phenomena of the towns and industrial districts but rather something that agricultural workers instigated too. In a short section in his magisterial Wretched faces, and later reprised in a section in a chapter in Randall and Charlesworth's Moral economy, Wells has argued that even if the evidence for rural riots is 'sparse', agricultural labourers did engage in protests -

${ }^{27}$ Roger Wells, 'Social protest, class, conflict and consciousness, in the English countryside, 1700-1880', in M. Reed and R. Wells, eds., Class, conflict and protest in the English countryside, I70o-I880 (London, 1990), pp. 121-98, at pp. 121-47; John Burnett, Plenty and want: a social history of diet in England from ${ }_{1} 8_{15}$ to the present (London, 1983), p. 6; Roger Wells, Wretched faces: famine in wartime England, I793-I80I (Stroud, 1988), pp. 161, 294.

28 Charlesworth, 'From the moral economy of Devon', p. 210.

29 Bohstedt, Riots and community politics, passim.

$3^{\circ}$ Charlesworth and Randall, 'Morals, markets and the English crowd', p. 203; Adrian Randall and Andrew Charlesworth, eds., The moral economy and popular protest: crowds, conflict and authority (London, 200o), p. 23.

$3^{1}$ Randall, Riotous assemblies, p. 154 . 
both overt and covert - over the availability and price of foodstuffs, though from the 179 os there was an increasing tendency to juxtapose food prices with wages and poor relief. Many of the protests, reckons Wells, were not food riots per se but still 'drew on the same moral economy tenets', for instance taxation populaire enacted against itinerant bakers and the detention of seed potatoes and cabbages in rural Somerset. ${ }^{32}$ Further, as Roger Wells claims, the record of food rioting in rural communities is 'hopelessly defective', riots that involved small numbers and little violence often being deemed 'too minor' to warrant attention from the press or the judiciary. 33 In the words of Charlesworth and Randall, writing on the 1766 national wave of food rioting in the context of the English west, 'it was the larger actions... of the earlier riots which caught the eye of the press and observers and dominated the courts'. The later actions of smaller 'mobs' who 'roamed' the countryside to the north of Stroudwater in Gloucestershire and mobile 'mobs' in neighbouring Wiltshire were 'generally under-recorded'.34 Further, rural resistances were less likely to get reported in the provincial press anyhow due to the fact that the geographies of reporting networks - and of the places of newspaper publication-left large areas of the countryside without systematic coverage. 35 Whatever the limitations of the archive, and its structuring effects, the point remains: rural food riots have been all but ignored, and no systematic attempt has been made to understand them as important phenomena.

\section{I}

In May 1 757, a 'mob', reportedly 2,ooo strong, gathered at Hurst Green, then a small hamlet seven miles north of Battle on the London Road in the Sussex Weald. The size of the gathering is in all likelihood an exaggeration, though Hurst Green was only three miles distant from Hawkhurst, the centre of a large smuggling and criminal gang whose operations had stretched as far west as Dorset until being suppressed in 1749. There was the local organizational ability to raise quickly a large, mobile assembly. Likewise, taking away a wagon loaded with corn would have required considerable force. Only military intervention - a file of musketeers - managed to 'appease' the mobile crowd,

$3^{2}$ Wells, Wretched faces, pp. 161-3; idem, 'The moral economy of the English countryside', in Randall and Charlesworth, eds., Moral economy and popular protest, pp. 209-72. Arguably, the best attempt to locate the moral economy in a rural context is Peter Jones's 2007 paper, although the focus of Jones's paper falls on the period after the decline of food rioting: Peter Jones, 'Swing, Speenhamland and rural social relations: the "moral economy" of the English crowd in the nineteenth century', Social History, 32 (2007), pp. 271-9o.

33 Wells, Wretched faces, p. 161.

34 Charlesworth and Randall, 'Morals, markets and the English crowd', p. 202.

35 Carl Griffin, 'Knowable geographies? The reporting of incendiarism in the eighteenthand early nineteenth-century English provincial press', Journal of Historical Geography, $3^{2}$ (2006), pp. $3^{8-5}$. 
with two of the 'ringleaders' arrested and lodged in Horsham Gaol. $3^{6}$ The mid-century Weald was a deindustrializing landscape, the once thriving cloth industry having collapsed at the end of the seventeenth century and the iron industry hanging on only at a few specialist furnaces and forges. It was, in short, agrarian; all services and trades supported labour in the fields, hop gardens, orchards, and woods. 37

If the scale of the Hurst Green riot was atypical, its form did typify many rural food riots: crowd actions attempting to prevent the 'export' of grain and flour from the community. Thus elsewhere in 1757, a wagon loaded with flour was stopped by the 'poor' at agrarian Ogbourne St Andrews whilst en route from Marlborough to Swindon, despite the presence of two magistrates. The owner, a large dealer, was obliged 'to have it back', that is to say to retail the flour locally. At Lavington in early summer, a wagon loaded with wheat belonging to a Melksham baker was stopped and 'in a riotous manner' eleven sacks of grain were thrown out of the wagon, for which one man and two Lavington women were tried and found guilty at the Wiltshire Assizes. $3^{8}$ Less dramatic was the seizure of a wagon loaded with flour at Rook's Hill en route to nearby Chichester on 17 June by a 'mob of women', but again this incident spoke to the depth of feeling in the countryside about food being exported from agrarian communities. 39 Thirty-eight years later in early 1795, one of several such riots in Sussex likewise involved only women, a mocking report in the Lewes press relating that a 'little мов оF wOMEN' had attempted to assail a miller's cart laden with grist at Sidley Green - a small squatters' settlement on the agrarian northern fringe of Bexhill - but that the miller had got 'clear of his petticoat assailants'. $4^{\circ}$

During the $1795^{-6}$ crisis, the countryside of North Yorkshire was the scene of the repeated stopping of wagons loaded with wheat and flour. Agricultural labourer Christopher Ellis and spinster Mary Jackson were arrested for stopping a wagon loaded with sacks of wheat at Carlton on 14 July, the sacks being opened and eight bushels of wheat 'scattered about the ground and spoiled' for which both expressed their regret, presumably only to save a sentence. A wagon journeying from Eaglescliffe, County Durham, to Topcliffe Mill, near Thirsk, was stopped at Yarm at 6.3oam on 11 December by Ann Doughfoot and Ann Gibson, both married to agricultural labourers, who said that they wanted the corn 'and would have it'. They then 'made a great noise and collected a great number of people, men and women alike, who

$3^{6}$ Sussex Weekly Advertiser, 9 May 1757; Nicholas Rogers, Mayhem: post-war crime and violence in Britain, I748-I753 (New Haven, CT, 2012), pp. 122-30.

37 Lorraine Flisher and Michael Zell, 'The demise of the Kent broadcloth industry in the seventeenth century: England's first deindustrialisation', Archaeologia Cantiana, 129 (20o9), pp. $239-56$.

$3^{8}$ Salisbury Journal, 17 Jan., 25 July, and 1 Aug. 1757.

39 Sussex Weekly Advertiser, 27 June 1757.

$4^{\circ}$ Ibid., 23 Feb. 1795 . 
immediately assembled in a riotous manner about the cart' which was then unloaded and twenty-two bushels of wheat 'riotously carried away'. The two Anns and John Wartors, a weaver, and labourer William Martin were arrested, tried at the Quarter Sessions, and sentenced to six months' imprisonment. The extensive parish of Aysgarth was the scene of repeated mobilizations in February 1796. The first, on 4 February, involved the stopping of two carts laden with wheat and wool at Thoralby en route to Kettlewell; another on the 19th involving the stopping of a cart laden with wheat, flour, and cheeses at Bainbridge and bound for Kendal, another five days later involved the stopping of a cart loaded with oatmeal at West Burton. Different individuals - women and men - were arrested and tried for the different riots (and in all three cases assaults against the owner of the various foodstuffs) and provided a crosssection of plebeian occupations in the Dales: agricultural labourers, woolcombers, cordwainer, butcher, an innkeeper (on 4 February at Thoralby but resident at West Burton, and whose wife was arrested for the riot at West Burton on the $24^{\text {th }}$ ), and, improbably, a dancing master. And while we do not know the occupational breakdown of all those involved, the majority of those arrested were agricultural labourers. $4^{1}$

If the stopping of wagons and carts was arguably the defining feature of the rural food riot, taxation populaire and the straightforward seizing of goods were also important protest forms too. Many of these incidents were modest affairs and would not have met Bohstedt's qualification for his riot sample. The stopping of a bread cart belonging to a Yeovil baker by the 'labouring people' at Holnest, Dorset, in July 1795 was outwardly an exceptionally modest affair. The baker was persuaded to sell them the bread-whether through fear or through appreciating that 'they were in great want' is unclearand those gathered 'honourably paid the full price for it' and then 'went away in a most peaceable manner'. A 'similar circumstance' also took place at nearby Holwell where the people took what they wanted, paid for it, and peaceably departed. This was taxation populaire done differently, mobile traders the target rather than markets and shops; ostensibly market transactions, if made in unusual circumstances albeit 'peaceable' and 'honourable'..$^{2}$ Bread and flour were not the only targets. Five years later during the next subsistence

$4^{1}$ Calendar of Michaelmas Sessions 1795, North Yorkshire Record Office (NYRO), QSB $1795 / 4 / 5$; Presentments of Ellis and Jackson, NYRO, QSB 1795/4/5; Informations of Ellis and Jackson, NYRO, QSB 1795/4/8; Information of Matthew Hogg, and examinations of Ann Doughfoot, Ann Gibson, John Wartors, and William Martin, Epiphany Sessions 1796, NYRO, QSB 1796/1/8; Presentments of Doughfoot, Gibson, Warters, and Martin (Yarm); Michael Heseltine, Adam Marchbank, Elizabeth Moor, Elizabeth North, Elizabeth Whitehead, Isabella Moor (West Burton); Thomas Walker, Richard Lawson, James Kettlewell, Ann Metcalfe, and Phillis Sean (Bainbridge); John Francis, John Pybus, Francis Harmison, Margaret Mattison, Mary Etherington, and George Whitehead Easter Sessions 1796, NYRO QSB 1796/2; Leeds Intelligencer, 1 Feb. 1796.

$4^{2}$ Western Flying Post, 20 July 1795 . On the severity of the midsummer hypercrisis, see Wells, Wretched faces, pp. 106-19. 
crisis, at Cerne Abbas when a gardener tried to sell potatoes - a true famine food in $1800-$ and carrots at extortionate prices, the women collected together and in a cool and determined manner insisted on him delivering them at a shilling the peck for the potatoes and twopence a bundle the carrots. 43 Some such incidents were more muscular. On 2 March 1795, a furious taxation populaire incident occurred at Worth, an extensive but obscure north Sussex parish dominated by agriculture, the men only dispersing after a considerable struggle notwithstanding the intervention of grandee the earl of Sheffield. Several of the men were arrested and later examined by Sheffield, being released having received a stern reprimand. This was not the end of the matter though, for there were repercussions in the provisions politics of the parish: in early June a farmer's barn at Worth was targeted by incendiarists and destroyed.44

Limiting analyses of rural food rioting to only the classical food rioting forms, though, is to deny the often multifaceted and hybrid nature of rural collective actions over food. News that Messrs Webb and Fowle, a firm of millers in the Kentish Wealden parish of Lamberhurst, were exporting corn out of the immediate district occasioning a 'great scarcity and a sudden rise in prices in that part of the county' prompted two crowd actions in the course of a week in late January 1795 . Between 3 and $5 \mathrm{pm}$ on 22 January some forty people descended on the mill, not demanding grain or flour but instead threatening that, unless the price of flour had fallen to one shilling per gallon by the following Monday, four or five thousand people would pull down the mill and destroy all the corn and flour. The miller, after receiving advice from the magistrates, applied to the War Office for the assistance of some troops to protect his property; consequently a party of Warwickshire Militia were dispatched. This did nothing, however, to dissuade a 'large party' of the poor inhabitants from nearby Wadhurst and Ticehurst assembling at Lamberhurst five days later. On arriving at the mill, the protesters stated the same demand to several 'gentlemen' of the neighbourhood who were in attendance, evidently present in the knowledge that the second visit was then expected. The gentlemen acceded to the demand and the group dispersed.45 A similar assemblage of 'twenty or more people' at Edenbridge in Kent on 7 February not only demanded the price of wheat and flour be lowered but also that their wages should be raised. The four-hour tumult ended with six labourers, with twenty-three children between them, apprehended and later committed to the Assizes. All six men were found guilty of misdemeanour but fined only a shilling each. ${ }^{6}$ Millers were

43 Kevin K. Bawn, 'Social protest, popular disturbances and public order in Dorset, $1790-188_{3}$ ' (Ph.D. thesis, Reading, 1984), p. 13.

44 Sussex Weekly Advertiser, 9 Mar. 1795. See also Wells, Wretched faces, pp. 101, 425. For the Worth fire, see Sussex Weekly Advertiser, 8 June 1795.

45 Kentish Chronicle, 6 Feb. 1795; Charles Jaques, Harrietsham, to the duke of Portland, 23 Jan. 1795, The National Archives (TNA), HO 42/34, fo. 55 .

$4^{6}$ Indictment of Eatonbridge (sic) rioters, Kent Lent Assizes 1795 , and calendar, TNA, Assi 94/1399; Kentish Gazette, 2o Feb. 1795. 
also the subject of a series of crowd actions in Sussex during the $1800-1$ crisis, all of which were led by or otherwise involved women. Millers were attacked at Northchapel; women, men, and children paraded then hanged and burned the effigy of a miller at Boreham; while a millers' cloth used to dress the popularly hated brown flour was torn to shreds by a crowd of women who then threatened to destroy the rest of his equipment at St Leonard's Forest. 47

Another way in which rural food rioting has been underplayed is by focusing only on the major national waves of food rioting, when, crudely put, the example of market town risings encouraged the populace to rise in other nearby towns, thereby distorting the geography of the overall record. For instance, in Dorset food riots occurred in the small market town of Beaminster in November 1764 and in agrarian Marnhull and Stalbridge in 1765 . The same year, a series of riots occurred in the countryside around Bradford-uponAvon (Wiltshire) where ' $[\mathrm{t}]$ he common people...stop almost every wagon that passes round...to prevent it from being exported'. Events centred on Tenterden in the Weald of Kent in 1768 were no less complex. The riotous group that had assembled there had the intention of 'raising a mob' to meet at Wood Church Green - an emergent squatters' settlement on the manorial waste-on 30 May to force the farmers to sell their wheat to the millers or poor people at $£_{10}$ a load, threatening to destroy the mills of those millers who paid over £1o. Moreover, when three of their number were arrested and conveyed through the streets of Tenterden on the way to the County Gaol at Maidstone, a 'mob' assembled 'in a very daring manner' and rescued them. $4^{8}$ The mobility of the Woodchurch group was mirrored by a similarly mobile 'Mobb of Reselute Felows' who 'Risd' at Bere Regis in central Dorset - a parish that was central to the diffusion of Swing in Dorset some forty years later-on 17 May 1790 before going to Kingston and 'forst men to go with them Down ye Vale' in what a local diarist noted was 'A very Scandelous Action.' 49

47 Reading Mercury, 23 June 1800; Sussex Weekly Advertiser, 9 Feb. 1801 . The role of women in food riots remains a contentious area. See Bohstedt, 'Gender, household and community politics', passim; idem, 'The myth of the feminine food riot: women as proto-citizens in English community politics, 1790-1810', in D. Levy and H. Applewhite, eds., Women and politics in the age of democratic revolution (Ann Arbor, MI, 1990), pp. 21-6o; and Thompson, Customs in common, ch. 5 .

$4^{8}$ Barbara Kerr, Bound to the soil: a social history of Dorset (London, 1975), pp. 95-6; Wells, 'Social protest', pp. 156-7; Kentish Gazette, 20 Mar. 1765 and 28 May 1768 . The Tenterden riot was particularly complex. The riotous gang that had assembled there had the intention of 'raising a mob' to meet at Wood Church Green on 30 May to force the farmers to sell their wheat to the millers or poor people at £1o a load, and threatening to destroy the mills of those millers who paid over £10. Moreover, when three of their number were arrested and conveyed through the streets on the way to the County Gaol at Maidstone, a 'mob' assembled 'in a very daring manner' and rescued them: Calendar of Home Office Papers, George III, I 766-I 769, II, p. 342 .

49 Memoranda and accounts of members of the Gould family of Bere Regis, entry for 17 May 1 79o, Dorset History Centre, D 1/PH/2. On Bere Regis's role in Swing, see Griffin, 'Culture of combination', pp. 474-5. 
The English countryside was evidently a key theatre for the playing out of food politics through riot. Food riots were not just of the towns. Further, the importance of other forms of crowd action that classical models of the resort to food riot do not capture also attests to the need to read the archive not to find evidence that simply reinforces our existing models but instead in a way that is sensitive to rural people's everyday engagements with food. If Thompson's moral economy model speaks powerfully to the field of force that existed between food rioters, the authorities, and millers and dealers, we do well to remember that this triangulation did not always play out in the market place and nor was it always confined to exclusively over concerns with the marketing of food. Indeed, the triangulation that mattered most to many rural residents was that between food, wages, and poor relief, and this relationship informed many crowd actions well into the nineteenth century. $5^{\circ}$

\section{I I}

On the evening of Wednesday 24 September 1800 , information was received in Winchester of an expected riot the next day at New Alresford, some eight miles to the west. Alresford was a small market town with a population of only $1,13^{2}$ in 1801 . Much of the parish was given over to agriculture, while the primary economic function of the town - such as it was - was to service the extensive agricultural hinterland of fertile arable lands and extensive sheep walks on the South Downs. Well connected to much of the county, including the key urban centres of Southampton and Winchester through the River Itchen and the Itchen Navigation, the ancient Thursday market at Alresford was of an importance that far outweighed the size of the settlement. In 1774, it was reported to be 'one of the greatest markets in Hampshire for wheat and barley, there are frequently above one hundred loads of wheat sold in a day'. An expected riot, then, was generative of considerable anxiety, especially so at the end of yet another deficient harvest. A detachment of the Fawley Light Dragoons accompanied by the Flintshire Militia was dispatched on the morning of the market, but 'finding no symptoms of disturbance' the militia left in the afternoon. That evening, however, 'considerable numbers assembled at Alresford from the adjacent parishes' armed with 'staves, sticks and other offensive weapons' and proceeded to 'hoot and hiss the Farmers and Millers', presumably ensconced in the inns. The arrival of three magistrates who 'expostulated with the multitude... [making] every mild and rational argument' failed to persuade those gathered from 'tumultuous behaviour'. So too did the reading of the Riot Act, and continuing 'in a state of outrage' the Light Dragoons were called upon to parade the streets in the hope of dispersing the crowd. This too failed, the Light Dragoons 'patiently bearing the insults of the populace'.

$5^{\circ}$ Thompson, 'Moral economy', passim. On this deepening dynamic, see Wells, 'The moral economy of the English countryside'. 
A detachment of the Berkshire Militia and, improbably, a group of Cornish miners then being in town escorting some French prisoners, were also called upon. But the magistrates 'finding nothing but force could restore order' directed the Light Dragoons to charge - bearing only 'the flat of their swords' - the 'ill-advised multitude' then 'fled in all directions' leaving the streets empty. No one was mortally wounded, though, so it was reported, 'several of them will have feeling cause to lament their not timely taking the previous advice of the Magistrates'. Nine prisoners were taken the next day, four of whom-all male labourers from New Alresford - were duly tried, three being found guilty of riot at the Hampshire Michaelmas Quarter Sessions. ${ }^{51}$

This was not a classic market town food riot. There was no attempt at taxation populaire, no seizing of foodstuffs, no attacks on the property of dealers and millers. Perhaps the early arrival of the military that morning acted to delay the arrival of the 'multitudes' from the surrounding countryside, though being a Thursday we might reasonably expect all those involved to be at work. Indeed, the evening assembly seems highly likely to have been deliberate and organized in advance; after all, the presence of the Light Dragoons did nothing to stop people flooding into the town. Nor was New Alresford a typical market town, Alresford fitting Bohstedt's model of a 'small agrarian village' rather than a 'stable, medium sized town' given its small population. $5^{2}$ Given that the arrests were made the next day it is highly probable that those seemingly most active and, critically, known to the (six) witnesses were targeted, hence the prisoners taken all being Alresford residents. But reports were clear, this was a riot of the agrarian environs not of urban consumers, an act to intimidate farmers and millers (and ultimately bakers) in the hinterlands of Alresford. This was a rural food riot. Perhaps it was 'undisciplined' in the narrow sense that it does not neatly fit the moral economy model of crowd actions, but no violence was proffered, and no property taken or damaged; the gathering planned and co-ordinated. It was far from a spontaneous, unruly free-for-all.

'Country people' could-and did-organize to engage in large-scale food riots in and of the countryside. Indeed, the examples are legion. As the above example attests, those resident in the rural environs of market towns had good reason to direct their anger to urban markets given that this was the place that farmers, millers, dealers, and bakers came together. The market town acted as the locus for the trading and retail of food in the locality. Even rural higglers and hucksters, as Wells has shown, secured their supplies from urban dealers. 53 Some such market towns were the repeated focus of the ire of agricultural workers over several decades. Petworth, in West Sussex, saw

${ }^{11}$ Hampshire Telegraph, 29 Sept. 1800; Michaelmas Quarter Sessions 180o, Indictments of John Tubb, 50, John Kett, 26, Simba Miles, 25, and Robert Shepherd, 28, for riot at New Alresford, Hampshire County Record Office, Q9/1/483.

$5^{2}$ Bohstedt, 'Gender, household and community politics', p. 106.

53 Wells, Wretched faces, pp. 31-2, 84 . 
mobilizations that primarily involved rural residents in 1800 (fifty labourers entered Petworth to complain that their families were nearly starving); 1796 (a miller was burnt in effigy for having 'prevented the proper reduction in the price of flour in the neighbourhood); 1795 ('country people' received 'countenance' from the militia); and 1790 (between one and two hundred of 'the peasantry' assembled in the town with large sticks to complain at the price of flour, the crowd claiming 'that they might as well be killed at once, as starved to death' adding 'they would have flour cheaper...or they would Grind the Miller').54

Petworth was also at the centre of one of the most extraordinary food rioting episodes in the history of south-eastern England, a series of protests that lasted for two days in July 1757 . Initially, a 'mob' of 5 oo men and 100 women and children 'rose' in Petworth to visit 'jobber' Hampton to offer to buy the wheat hoarded in his warehouse. This being refused, they broke in and took seven loads and four bushels which they took to the town green and placed out for anyone to help themselves to, some filling bags, others carrying corn home in the folds of their clothes on their laps. The following day, the 'same people'though presumably the precise composition of the gathering was somewhat different-assembled and went to the hamlet of Adversane at agrarian Pulborough, some eight miles east of Petworth - and took more corn, before then going to Hardham to search a further mill but finding no more corn than was necessary for the miller's family left without taking anything. Growing in number as they went about the countryside, and 'countenanced by great Numbers who give them Victuals and Drink', there were even reports that they were 'so large now that they talk of dividing into two bodies one to take the west, the other the eastern road'. We know that some of the group resolved to go to Chichester, while others went to Arundel, where they seized a barge laden with corn which they then began to tow away before being stopped by a party of Dragoons dispatched from Chichester. We cannot be certain as to the precise composition of this mobile group, but reports stated that '[t]hey are all armed, some with prongs, some with picks, some with shovels, and such kind of weapons'. This, then, was evidently a group in which agricultural workers played a major role. 55

Perhaps the above example is extreme in terms of the ambition and scope of the protests, but of seven food riots uncovered in the archive for Sussex in $175^{6-7}$, five involved bodies of rural labourers entering market towns, the other two cases rural attempts to prevent exports. $5^{6}$ The food riot at Lewes involved, according to the town's press, 'nearly 200 poor people [coming] in

54 Sussex Weekly Advertiser, 10 and 17 May 179o, 25 Apr. 1796, and 24 Feb. 1800 ; Maidstone Journal, 21 Apr. 1795.

55 Sussex Weekly Advertiser, 13 June 1757; Salisbury Journal, 13 June 1757.

$5^{6}$ Sussex Weekly Advertiser, 2 Feb., 9 May, 13 and 27 June, 15 Aug. 1757 ; Salisbury Journal, 13 June 1757; D. Vaisey, ed., The diary of Thomas Turner, I 754-I 765 (East Hoathly, 1994), pp. 82 and 107 . 
a body to the town complaining of the great price of corn' and targeted the warehouse of a dealer believed to be engrossing corn. The people-no gender identities were reported or can be inferred - came from 'several neighbouring parishes' of East Hoathly, some eight miles from Lewes. Thus, again, we have clear evidence not only of the leading role of agricultural workers but also organization and co-operation over multiple parishes and a willingness and ability to travel considerable distances to market towns to right wrongs. 57 Likewise, a group of men from the Dorset parishes bordering the New Forest and Cranbourne Chase not only visited the small market town of Fordingbridge in May 1757-being armed with axes, hooks, and clubs-to visit one mill that was milling barley for baking the popularly loathed barley bread, but went on to visit several other mills in the New Forest travelling at least a further seven miles from Fordingbridge. $5^{8}$

This was not something confined to the crises of the mid-eighteenth century or to just certain locations with a long history of food riots. Rather, it typified the resort to food rioting per se in both the first phase of rioting in the early spring of 1800 and comprised a significant proportion of food riots during the intensive wave of rioting in late August and September 1800 . Indeed, the archive abounds with examples of rural workers either instigating or playing a significant role in market town food riots. The men indicted at the Hampshire Quarter Sessions for a riot at Romsey in September came from the small village of Chilworth, some five miles distant, although the mayor confirmed to the Home Office that those engaged in the riot had come from 'various parts of the country'. A few days after the Romsey riot, a threatening notice was 'stuck up' in the town, the mayor informing Home Secretary Portland that a plan was afoot by a 'formidable body...many hundreds' of 'New Foresters' to visit Romsey. This was not some trifling worry, the mayor relating that they were 'more apprehensive about [a visit from the New Foresters] as the[ir] proceedings throughout have been systematical'.59 Just over the county border at Farnham, those assembled at the market had shown 'symptoms' of riot and threatened to return the following week. This was made good on 25 September when the 'country people' again gathered in Farnham armed with large bludgeons. ${ }^{60}$ In Sussex, at Horsham, agricultural labourers from the neighbouring villages were also responsible for invading the town, whilst labourers from coastal Pevensey intended to march to the

57 Sussex Weekly Advertiser, 7 Feb. 1757; Vaisey, ed., The diary of Thomas Turner, pp. 82 and 107.

$5^{8}$ Salisbury Journal, 9 May 1757.

59 John Latham, mayor of Romsey to Portland, 2 and 4 Sept. 1800 , TNA, HO $42 / 51$, fos. 20 and $4 \mathrm{O}^{-1}$; Calendar and Indictment of Joseph Mizzlebrook (not in custody), George Waite and Benjamin Wren, labourers, Chilworth, Hampshire Michaelmas Quarter Session 1800, Hampshire County Record Office, Q9/1/483.

60 William Mitford, Pinhill, Surrey, to the Home Office, 25 Sept. and 8 Oct. 18 oo, TNA, HO 42/52, fos. 32-5; Hampshire Chronicle, 29 Sept. 1800. 
market town of Hailsham to pull down a mill. ${ }^{61}$ In neighbouring Surrey, 'several bodies' of 'labouring men' who were en route to Dorking on learning that the magistrates were aware of their plan and were preparing to meet them with both a civil and military force 'returned to their respective homes much ashamed of their conduct'. A small number continued to Dorking and lobbied the Bench for relief, being promised that 'in consequence of their good behaviour be ordered such parochial assistance as required'. ${ }^{62}$ Elsewhere, at Blandford in Dorset in the spring of 1800 , 'a very serious Mob, not only of our own people, but from the neighbouring villages, collected in our Streets' demanding bread at their own prices. They then marched en masse to a mill three miles off where the local yeomanry finally dispersed them. ${ }^{63}$

A broadly similar dynamic was also true of many of the collective actions over food in the early months of 1801 . The example of Horsham in mid-Sussex is instructive. An 'assemblage' of labourers on 7 February applied to the sitting magistrates regarding the 'price' of grain. Whilst we do not know what was said, the 'men' left 'without tumult' suggesting placatory words if not necessarily immediate action. Two weeks later, a further gathering of labourers 'from different parts of the neighbourhood' occurred in the town, many of the men reportedly 'armed' with sticks. This more muscular intervention generated considerable alarm, not least amongst the local magistrates and gentry. Thus, when it became known that 'a numerous meeting of the lower orders', 'chiefly from the eastward of Horsham', was intended to be held to coincide with the corn market on 7 March, the home secretary was requested to support the 'appearance of force', without which it was believed 'they will mediate mischief' ${ }^{6} 4$

We do well to remember, though, that while agricultural workers were often the instigators of urban food riots, and were even occasionally invited by their urban cousins, this was always an uneasy compact. On the evening of 13 April $\mathbf{1 7 9 5}$, in consequence of an inflammatory hand-bill that had been generally circulated through Chichester and the neighbouring villages, 'a considerable body of the lower orders' of the city assisted by some 'country people' assembled in the city to force a reduction in the price of provisions. When later joined by a 'great number' of privates from the Herefordshire Militia, those assembled also marched out of the city to a farmer in a neighbouring village, who, it was alleged, had been withholding corn from the market. The farmer was compelled to promise that he would bring his corn to market and sell it at

61 Sussex Weekly Advertiser, 9 Feb. and 16 Mar. 1801 ; Midleton, Peper Harrow, to Portland, 19 and 20 Feb. 1801 , Horsham Bench, 1 Mar. 1801, Richmond, Goodwood, 16 Feb. 1801, enclosing H. Shadwell, Ringmer to Richmond, 15 Feb. 1801 , all to Portland, TNA, HO 42/61, fos. $160-1,162-3,178-9$, and $156-8$.

${ }^{6}$ Lord Leslie, Dorking to Portland, 7 Mar. 18 oo, TNA, HO 42/49, fos. $359^{-60 .}$

63 Bawn, 'Social protest', p. 13.

64 Sussex Weekly Advertiser, 9 Feb. 1801; Kentish Gazette, 13 Feb. 1801; Messrs Shelley and Endcroft, JPs, Horsham to Portland, 1 Mar. 1801, and S. Shelley, Firle Place to Portland, 4 Mar. 1801 , TNA, HO $42 / 61$, fos. $178-9$ and $189-90$. 
five shillings a bushel. ${ }^{6} 5$ This was a deliberately assembled coalition of poor consumers that transcended the rural and the urban, but the compact was fragile. The militia men complained to the Chichester authorities that the 'country people' were relieved by their parishes and by subscriptions, and therefore had access to bread. The soldiers did not need bread money but needed bread itself. Yet the very fact that the 'country people' not only made the effort to journey to Chichester but then to engage in this coalition of the wretched is substantiation enough that many rural workers-whether in receipt of relief and or charity or not-were in no better position than their urban kin. 66 'Country people' were evidently not only prepared to resort to the tools of food rioting in their own communities but also in the nearby market centres too.

\section{V}

Beyond extensive food riots in Paris and elsewhere in France, and in several parts of Ireland, Scotland, and Wales, 1740 witnessed the first truly national wave of food rioting in England. Riots occurred throughout the land, from Newcastle and Sunderland in the north, through Staffordshire, Norfolk, Essex, Gloucestershire, to Cornwall. ${ }^{6}$ Many of these were market-place riots wherein townsfolk or 'invading' colliers engaged in taxation populaire, but arguably the defining feature of the 1740 riots were attempts to prevent the export of grain and flour, many of which occurred in the countryside. Similarly, several other crowd actions also occurred in rural settings. Of course, just by virtue of occurring in the countryside does not necessarily make a food riot of the countryside. But simply to dismiss riots that had their roots in the rural for being led by industrial workers is to allow ourselves to be blinded to the involvement of others. For instance, the Kingswood colliers were active visiting millers and others thought to be withholding corn in the Gloucestershire and Somerset countryside in the vicinity of Bristol and Bath in late September 1740 before a delegation was sent to meet with the mayor. We know too from reports that

65 Sussex Weekly Advertiser, 20 Apr. 1795; Maidstone Journal, 21 Apr. 1795; duke of Richmond, Goodwood, 13 Apr. 1795, enclosing Richard Murray, Chichester to Richmond, 13 Apr. 1795 , G. Pecknell, Arundel, 14 Apr. 1795, to Rt. Hon. William Windham, TNA, WO 1/1092, fos. $139-47$.

66 Duke of Richmond, Goodwood, to Lord Windham, 13 Apr. 1795, TNA, WO 1/1092, fos. $139-47$.

${ }_{67}$ John Bohstedt, 'Food riots and the politics of provisions in early-modern England and France, the Irish Famine and World War I', in M. T. Davis, ed., Crowd actions in Britain and France from the Middle Ages to the modern world (Basingstoke, 2015), pp. 101-23; K. Lloyd Gruffydd, 'The vale of Clwyd corn riots of 1740', Flintshire Historical Society, 27 (1975-6), pp. 36-42; Philipp Rössner, 'The 1738-41 harvest crisis in Scotland', Scottish Historical Review, 9o (2011), pp. 27-63; Joyce Ellis, 'Urban conflict and popular violence: the Guildhall riots of $174^{\circ}$ in Newcastle upon Tyne', International Review of Social History, 25 (1980), pp. 332-49; Charlesworth, ed., Atlas of rural protest, ch. 3.4; Bohstedt, Politics of provisions, ch. 4 . 
this was not one homogeneous, unchanging body but rather a more complex, heterogeneous, mobile multitude variously containing not just the dominant male colliers but also 'some weavers, colliers' wives and [an] abundance of other women'. The 'abundance of other women' also suggests not only that some of weavers in the throng were joined by their wives but also that other rural women were present; ergo members of labouring and artisan families. ${ }^{68}$ The colliers of Kingswood-colliers anywhere-were not sealed away from other rural workers. Those who formed the plebeian communities with them not only shared the same spaces but also many of the same problems. Kingswood may have developed as a squatters' community of miners from the mid-sixteenth century after the sale of Kingswood Forest by the crown but it remained planted in an agrarian and sylvicultural system. ${ }^{69}$

We need to be careful in not blithely assuming that just because certain occupational groups were notorious for their unruly behaviour that reports suggesting their sole involvement in a riot were always accurate. Indeed, the identifying 'faces in the crowd' approach, an abiding obsession in protest studies since the publication of George Rudé's 1959 The crowd in the French Revolution, $7^{\circ}$ has its limits. Outside of individuals and groups self-identifying themselves, we are necessarily reliant on either the legal records of those taken into custody and/or arrested or reports of the event, and both could be skewed by the involvement of those groups who were locally infamous. Reputations, after all, can lead to false representations and act to blind reporters to other realities. For instance, we know that, as with the Kingswood colliers, the freeminers of the Forest of Dean had a particularly fearsome reputation for lawlessness although as with their Kingswood brethren they were actually quick to resort to the law themselves in defending their interests $7^{1}-$ which tended to colour the judgement of those reporting on food rioting in the Dean. Riots in July $174^{\circ}$ began when highly organized miners traversed the district searching dealers' and millers' premises for grain bound for export and withheld supplies respectively. Three men-all miners-were tried and found guilty at the Gloucestershire Quarter Sessions for their involvement in a particularly 'notorious riot' and supposed attempt to destroy the dwelling house and mill of Joseph Sayer of Redbrook. $7^{2}$ But targeting miners for prosecution probably speaks as

68 Salisbury Journal, 30 Sept. 1740; Thompson, Customs in common, pp. 102-3; David Rollison, The local origins of modern society: Gloucestershire I500-I80o (London, 1992), ch. 9 .

69 Peter Large, 'From swanimote to disafforestation: Feckenham Forest in the early seventeenth century', in Richard Hoyle, ed., The estates of the English crown, I558-I640 (Cambridge, 1992), p. 397; Robert Malcolmson, "A set of ungovernable people": the Kingswood colliers in the eighteenth century', in John Brewer and John Styles, eds., An ungovernable people: the English and their law in the seventeenth and eighteenth centuries (London, 1983), pp. $85^{-127}$.

$7^{\circ}$ George Rudé, The crowd in the French revolution (Oxford, 1959).

$7^{1}$ Andy Wood, Riot, rebellion and popular politics in early modern England (Basingstoke, 2001), p. 78 .

$7^{2}$ Gloucester Journal, 22 July 1740; Derby Mercury, $3^{1}$ July 1740; Randall, Riotous assemblies, p. 108. 
much to a desire of the local magistracy and landowners to make an example of the colliers in an attempt to check their rebellious culture as it does to the occupational make-up of those present at the Redbrook riot. Given that Redbrook was a major smelting centre in the Dean, a famed copper works active until $174 \mathrm{O}$ whilst the village also contained an iron works, it seems improbable that other rural industrial workers were not present.73 Further, we know that the freeminers often combined their small-scale mines with petty agriculture, relying on the biotic resources of the forest to turn out livestock, and were otherwise reliant on the forest for pit prop timbers and, ironically, fuel. 74 Miners were not just miners but also commoners, peasant producers.

This complex hybridity - and explicit evidence of the involvement of those not engaged in industrial pursuits in the Dean in food rioting-came during the 1795 subsistence crisis with an even more muscular series of protests. On Saturday 30 October, a wagon load of barley was being taken to Gloucester market from Bollitree (Herefordshire, just beyond the bounds of the forest) when near the Lea Line it was 'beset by a number of colliers from the Forest of Dean'. Whilst the colliers were examining the contents, another wagon passed, this being loaded with wheat and bound from nearby Harthill. This was likewise 'taken to in the same manner', and both wagons were then 'taken off' to Drybrook where 'the people' divided up the corn and sent back the wagons and horses to their respective owners. The following Saturday, 'a party of foresters, chiefly from the neighbourhood of Lidbrook' stopped a further wagon loaded with wheat, this time taking it to the markethouse at Ross with 'the intention of selling it out on Monday morning at $8 \mathrm{~s} \mathrm{a}$ bushel'. The plan, however, was thwarted by a local magistrate who, supported by ten of the Essex Light Dragoons, had the corn reloaded onto the farmers' wagon on Monday morning and sent it off with a military escort. Within an hour, sixty foresters set off in pursuit of the wagon, pursued by the magistrate. Only the 'somewhat refractory' ringleader was arrested, the other foresters being persuaded to give up their plan to retail the grain and instead to return to their homes. The ringleader of these several 'outrages', and of a mobbing of a mill at Longhope, was not a freeminer but instead someone who got by through exploiting the resources of the forest and by living on his wits: William Stallard, who in the words of county historian H. G. Nichols, was a 'reputed highwayman, and noted deerstealer'. Stallard lived on the Upper Purlieu in the north-eastern corner of Ruardean parish at Hawthorns, an obscure place consisting of a small number of squatters' cottages cleaved from the waste, a part of the forest dominated by small farmsteads. 75 Stallard

73 Cyril Hart, The industrial history of Dean (Newton Abbot, 1971), passim.

74 Ibid., passim; Simon Sandall, Custom and popular memory in the Forest of Dean, c. ${ }_{1550-I 8} 2$ (Cambridge, 2013), esp. p. 24.

75 Henry Nicholls, The Forest of Dean: an historical and descriptive account (London, 1858), pp. 84-5; A. P. Baggs and A. R. Jurica, 'Ruardean', in C. R. J. Currie and N. M. Herbert, 
and his men were variably described as foresters and miners but this falls short of representing the complex lives of those who lived in and on the forest, lives that transcended one occupational label and embraced the industrial, the agrarian, and the sylvan.

Not only were many rural residents engaged in complex hybrid lives - occupationally, geographically, and in terms of their familial and kinship relations - but, as the above examples of the food riots at Chichester in 1795 and at New Alresford in 1800 attests, urban agitants sometimes actively sought the support of their agrarian neighbours. In this way, urban food riots assumed a complex heterogeneous sociality. 'Advertising' a planned riot in the surrounding countryside (as at Chichester) or the use of existing social networks to organize a collective action (as at Alresford) were clearly effective strategies in assembling collectivities that transcended easy classification. Another mode was through the involvement of highly mobile groups with pre-existing organizational structures that linked together town and country. One such occupation were journeymen papermakers, a group with, by the turn of the nineteenth century, an established record of trade union organization and collective action, and whose places of work - and journeys between their papermills - traversed the countryside. $7^{6}$

On Monday 22 September, $15^{\circ}$ people 'from the Country came into [Midhurst, Sussex] and distributed what they call'd a Proclamation', regarding the price of provisions making the cryer read it and ordering a printer to print it, which was refused. '[I]n all other respects', so the duke of Richmond related to the Home Office, 'they behaved quietly + refused drink that was offer'd to them' but stated their plan to return on Thursday at noon to 'to see their intentions carried into Execution'. Depositions were duly taken and two papermakers, then engaged at the mill at nearby Iping, were arrested 'without resistance' and subsequently committed to stand trial for riot at the West Sussex Quarter Sessions. It transpired that one of the Iping men had been to Godalming, another papermaking centre some twenty miles to the north in neighbouring Surrey, and heard that 'a large mob had assembled there' and had issued a proclamation. Having then met with the local magistrates, who did not object to the proclamation or its terms, they agreed to meet again a week later to see what would be done to lower the price of provisions. The Iping man brought with him a copy of the Godalming proclamation, 'on which the Paper makers agreed to make a Holyday + go to Midhurst to see what they could do with the Magistrates here'. On their way, the Iping papermakers also 'pressed' some labourers to join them 'threaten[ing] a man who remonstrated with them'. The Godalming proclamation, it transpired, had

eds., A history of the county of Gloucester, v: Bledisloe Hundred, St. Briavels Hundred, the Forest of Dean (London, 1996), pp. 231-47.

$7^{6}$ Leonard Rosenband, 'Comparing combination acts: French and English papermaking in the age of revolution', Social History, 29 (2004), pp. $165^{-85}$. 
been inspired by the second paragraph of a proclamation issued by the combined magistrates of several Surrey Hundreds:

They [the Surrey magistrates] have therefore thought proper to invite all persons to associate themselves for the purpose of discovering all practices which tend to enhance the prices of the necessities of life by any contrivance or conspiracy. It is the interest of all to carry this plan into effect.

As at Iping, several papermakers - from the Catteshall Mill, some little distance beyond Godalming town - were arrested and tried at the local Quarter Sessions. Whilst they pleaded guilty, the Bench resolved 'that under all circumstances [as] lenity was the measure most likely to occasion the affair to be buried in oblivion discharged the men'. In both places, the papermakers made great efforts to give the impression that they were acting on behalf of the community, at Iping through the impressment of agricultural labourers and at Godalming through acting on the instigation of a proclamation issued by 'the Inhabitants of the Town'.77 Just as their lives were not absolutely bounded by the parish, nor their circles of friends and acquaintances absolutely determined by their occupation, those who laboured in the fields often combined in heterogeneous groups in collectively enforcing their right to food at fair prices.

According to Randall in his survey of the riot in eighteenth-century England, agricultural workers took 'no part in such protests', because they 'neither had the "community solidarity" to riot nor the actual need, being able to fall back on the exploitation of commons, pilfering and below cost food from employers'..$^{8}$ Maybe in some places aspects of that were true, though by mid-century most agricultural workers were thoroughly enmeshed in market relations. They were not yet Marx's proletariat - for that required the deeper mechanization of agrarian practices to render their labour to a base levelbut they were still deeply aware that their ability to eek out anything more than a subsistence living was increasingly difficult. By 1780 , and in some places earlier, the real wages of male agricultural workers had begun a period of long-term decline, real wages for female agricultural workers had arguably begun to decline even earlier.79 Pilfering was an option for some, and certainly during the subsistence crises of the 1790 s prosecutions for the theft of grain markedly increased, but by then most agricultural workers - whether in the south or north, whether in the grain belts or more pastoral counties-were just like their urban cousins reliant on purchasing bread and did not have

77 Duke of Richmond, Midhurst, to Portland, 25 Sept. 180o, and William Milford, Pinhill, to Portland, 8 Oct. 1800 , TNA, $\mathrm{HO} 4^{2 / 5^{1}}$, fos. $455^{-7}$, and $42 / 5^{2}$, fos. $3^{2-5}$.

$7^{8}$ Randall, Riotous assemblies, p. $15^{2}$.

79 K. D. M. Snell, Annals of the labouring poor: social change and agrarian England, I660-I9oo (Cambridge, $19^{8} 5$ ), p. 59 . 
the means to grind their own flour or in the leanest of times the money to afford the fuel to bake it. ${ }^{80}$ Commons, where they existed-and that imprint was shrinking rapidly - undoubtedly offered something of a safety net, yet, as the example of the riotous New Foresters shows us, having an ability to exploit commonable resources (whether legally or otherwise) was no barrier to engaging in collective action nor a total shield from the market. Indeed, we know of the later Swing quasi-insurrection that threshing machine-breaking started precisely in those communities of the Elham Valley where, unusually for East Kent, several large remnant commons remained. ${ }^{81}$

Several of the above examples also attest to the importance of squatters' communities in rural food rioting. While the extent and social function of squatting in eighteenth-century England awaits its historian, some points are salient. First, squatters' communities-established or emergent-existed everywhere that commons and wastes remained, often, so what few studies we have suggest, tolerated by lords of the manor by virtue of their being another way in which commons could be monetized by charging manorial rents on squats. Second, such communities were literally and metaphorically at the edge: the edge of the common, the edge of the parish, the edge of the usual methods and modes of social control (the vestry, the church, the parish constable). In this way, not only was it relatively easier to engage in illicit and illegal activities but also a culture of independence developed. As the historian of Kent, Edward Hasted, proclaimed of the squatters' settlement of Stelling Minnis in east Kent, 'the inhabitants [were] as rude and wild as the country they live in' ${ }^{82}$ The third is rooted in a paradox. Squatting represented a critical way in which commons and wastes sustained individuals and families shielded from many aspects of agrarian capitalism. If their use of the common might in some ways serve to put food in their bellies, their exposure to the market was largely in relation to food. Ergo, squatters were even more sensitive to sudden movements in prices and exploitation, and given their distinctive cultures it is not too surprising that they took so prominent a role. Systematic research on the culture and economy of squatters' communities is vital, though, in better understanding their broader social function.

If the where of food rioting matters - both in terms of where food riots took place and where those who took part resided and worked - the complex spatialities presented speak to a need to move beyond neat, geographically bounded models in our understanding of plebeian lives in the long eighteenth century. This is not to say that we should do away with the rural and urban as

\footnotetext{
80 Douglas Hay, 'War, dearth and theft in the eighteenth century: the record of the English courts', Past E् Present, 95 (1982), pp. 117 -6o; Burnett, Plenty and want, p. 6.

81 Carl Griffin, The rural war: Captain Swing and the politics of protest (Manchester, 2012), pp. $87-90$.

${ }^{8}$ Carl Griffin, 'Enclosures from below? The politics of squatting and encroachment in the post-Restoration New Forest', Historical Research, 91 (2018), pp. 274-95; Edward Hasted, History and topographical survey of the county of Kent, VIII (Canterbury, 1799), pp. 91-2.
} 
categories of analysis, undoubtedly both acted to frame the experience of everyday life. Rather, it is to assert that many lives were far more fluid in terms of both movements, economic, kinship, and social connections, and interdependence. Thus, at once it is useful to assert that those who lived in the countryside had many reasons to visit the towns, and vice versa, but in other ways this is to deny complexity and to assume a universality of experience that rests on the urban-rural dualism. Many market towns within their bounds had extensive areas of agricultural land and even commons; many other urban settlements also had growing 'edge' settlements (whether suburbs or squatters' settlements that developed on the fringe of commons and manorial boundaries) that were defined by the sociality of population-dense urban living but were marked by the dual lives of their residents getting by in combining agricultural and other labouring work, poaching, and families and friends who lived in the villages they had left behind. The division between many large villages and smaller market towns, not least those with a decaying industrial base, was arguably legal and political rather than experiential. Relying on categorizations of settlement in explaining geographical and social difference is, by and large, to create anachronistic simplification that forces our attention away from the complexity of lives as lived.

Community solidarity was no doubt hugely important in helping to forge stable plebeian coalitions that could readily be mobilized in the defence of their collective interests. Certainly, the work and community bonds that tied together weavers and colliers were strong and central to their particular practices and histories of food rioting. ${ }^{8} 3$ We do well to remember though, as Jane Humphries and Benjamin Schneider have recently shown, that spinning was organizationally fragmented and relatively low-wage. ${ }^{84}$ We also know that agricultural workers were bound together in both their parishes and their wider districts by the same experiences of work, by the same experiences of pauperization, and, from the final decades of the century, the same experiences of increasingly stingy poor relief tied to the surveillance strategies adopted by vestries and overseers. We know too that in some places by the 1790 , agricultural workers combined to demand higher wages, and even to strike from work in an attempt to enforce their demands. ${ }^{8} 5$ Of course, to claim that all agricultural labourers engaged in collective action to defend their interests and their ability to procure fairly priced food would be fallacious, maybe some-

83 Andy Wood, The politics of social conflict: the Peak Country, I520-I77o (Cambridge, 1999), esp. chs. 9 and 10; Adrian Randall, Before the Luddites: custom, community and machinery in the English woollen industry, I776-1809 (Cambridge, 1991), passim; idem, Riotous assemblies, esp. chs. $3^{-6 .}$

84 Jane Humphries and Benjamin Schneider, 'Spinning the industrial revolution', Economic History Review, 72 (2019), pp. 126-55.

${ }_{5}$ Griffin, 'Culture of combination'; Roger Wells, 'Tolpuddle in the context of English agrarian labour history, $1780-185^{\circ}$ ', in John Rule, ed., British trade unionism: the formative years (London, 1988), pp. $112-27$. 
like those at Iping - resisted others' attempts to incite them to action. But nor did all urban and industrial workers so resist. Plenty of stable, medium-sized towns forewent food rioting altogether-and plenty of agrarian parishes embraced muscular provisions politicking. The evidence is neither thin nor flimsy. That agricultural workers not only engaged in but also instigated food riots in the countryside and in the towns is emphatic. And that conceptually hermetically sealed categorizations of rural workers - agricultural vs industrial - is to deny the far more complex relationships and roles groups such as weavers and colliers had with the agrarian.

It is also true that agricultural workers found other ways of engaging in provisions politics. At times, of course, collective protest was incredibly risky. The extension of the net of poor relief as a result of Speenhamland-style income subsidy schemes in response to the crisis of $1795^{-6}$ undoubtedly meant that a far greater proportion of the agricultural population in the south and east were now deeper enmeshed in the local surveillant state with its obligations and deference. Yet, as Keith Snell has shown, deference had its limits, that which was outwardly deferential often masking a deep bitterness. This was a culture of deferential bitterness. ${ }^{86}$ Even that had its limits. During the $1800-1$ crisis, the tactic of agricultural labourers collectively protesting their lot to the local bench assumed a new primacy, their complaints not only regarding the unaffordability of provisions but also the inadequacy of wages and parsimonious poor relief. If the tactic was not new-for instance, in early 1795, thirty-seven paupers from Hurstpierpoint attended upon the Lewes Bench to complain that their parish officers had refused them relief-the relative frequency of the tactic compared to other collective actions over food in the countryside was now palpably different. ${ }^{87}$ Indeed, in the countryside in particular, from the 1790 , the demands of protesters made during subsistence crises began to focus less on food - though it remained the primary focus - and more on wages and poor relief. A striking articulation of this changing dynamic came when in February 1801, 300 'country people' from the Weald descended on the Lewes Bench: those from Buxted wanted lower prices; those from Framfield threatened to strike 'if they didn't live better'; whilst those from Chiddingly and East Hoathly wanted more generous poor relief. ${ }^{88}$ Occasionally, such protests took a more direct route such as when in April 1800 a 'number' of labourers assembled in Ardingly (Sussex) and went en

86 Carl Griffin, The politics of hunger: protest, poverty and policy in England, c. I750-c. I850 (Manchester 2020), ch. 3; K. D. M. Snell, 'Deferential bitterness: the social outlook of the rural proletariat in eighteenth and nineteenth century England and Wales', in Michael Bush, ed., Social orders and social classes in Europe since $15^{\text {oo }}$ (Harlow, 1992), pp. ${ }_{1} 5^{8-84}$.

87 On the increased importance of this tactic, see Wells, Wretched faces, p. 426; Griffin, Protest, politics and work, pp. 20, 107-8. For the Hurstpierpoint protest, see Sussex Weekly Advertiser, 9 Mar. 1795 .

88 TNA, HO $42 / 61$, fos. $15^{\mathrm{O}^{-}} 5$, duke of Richmond, Goodwood, to Portland, enclosing a letter from Henry Shadwell, Ringmer, to Richmond, both 15 Feb. 1801. 
masse to inform the parish officers that unless their wages were augmented they could not get bread for their families and would therefore 'become burthensome'. ${ }^{89}$

Beyond 1801 , in times of subsistence crises English workers - whether in the countryside or town - rarely turned to food rioting, the last sustained resort being by the Cornish miners in $1848.9^{\circ}$ Rather, poor workers turned to other forms of protest to gain redress, Thompson's moral economy now articulated in different ways. $9^{1}$ In some senses, this was not a sudden and dramatic shift, for whilst rural workers had long engaged in food rioting, they had also readily turned to other protest tools to gain redress during food crises. Indeed, to assume that food rioting was the only way in which poor consumers engaged in politicking over food is a gross oversimplification. Riot was, after all, a last resort; a brave act that might end in incarceration or upon the gallows.

In the towns, as Bohstedt has asserted, organized and systematic schemes were in times of crisis put in place - not just emergency subscriptions but publicly supported co-operative mills and bakeries - and acted to help quell popular anger that would once have found expression in riot. The role of popular politics in encouraging such schemes and promoting collective self-help was also a powerful force in preventing disturbance..$^{2}$ In the countryside, there were no such systematic mechanisms to deal with hunger, rather growing pressures on real wages - and post-1815 mass unemployment and underemploymentacted further to politicize wages and poor relief and to almost totally shift the attention away from the marketing of food as the critical nexus of protest. Hunger remained a potent political force, something the popularly hated New Poor Law of 1834 with its focus on the dreaded union workhouses with their meagre set dietaries based on the principle of 'less eligibility' deliberately played upon. It was just now rarely expressed in the form of the food riot that had once been a central part of the protest lexicon of agricultural workers. 93

\footnotetext{
89 Sussex Weekly Advertiser, 21 Apr. 1800.

9o Bohstedt, Politics of provisions, ch. 6.

$9^{1}$ Thompson, 'Moral economy', pp. 128-31; Roger Wells, 'The development of the English rural proletariat and social protest, $1700-185^{\circ}$ ', in Reed and Wells, eds., Class, conflict and protest in the English countryside, pp. 29-53, at p. 45; Peter King, Crime and law in England, I750-I 840: remaking justice from the margins (Cambridge, 2006), p. 33 n. 62; Randall, Riotous assemblies, ch. 6; Jones, 'Swing, Speenhamland and rural social relations', passim; Elizabeth Fox-Genovese, 'The many faces of moral economy: a contribution to a debate', Past $\mathcal{E}^{2}$ Present, $5^{8}$ (1973), pp. 161-8.

$9^{2}$ Boshtedt, Politics of provisions, pp. 231-40.

93 Griffin, The politics of hunger, esp. chs. 2 and 4 .
} 